\title{
Sports injury and illness incidence in the Rio de Janeiro 2016 Olympic Summer Games: A prospective study of 11274 athletes from 207 countries
}

\author{
Torbjørn Soligard, ${ }^{1,2}$ Kathrin Steffen, ${ }^{3}$ Debbie Palmer, ${ }^{4,5}$ Juan Manuel Alonso, ${ }^{6}$ \\ Roald Bahr, ${ }^{3}$ Alexandre Dias Lopes, ${ }^{7}$ Jiri Dvorak, ${ }^{8}$ Marie-Elaine Grant, ${ }^{9}$ \\ Willem Meeuwisse, ${ }^{2}$ Margo Mountjoy ${ }_{1}^{10}$ Leonardo Oliveira Pena Costa, ${ }^{11}$ \\ Natalia Salmina, ${ }^{12}$ Richard Budgett, ${ }^{1}$ Lars Engebretsen ${ }^{1,3,13}$
}

- Additional material is published online only. To view please visit the journal online (http://dx.doi.org/10.1136/ bjsports-2017-097956).

For numbered affiliations see end of article.

\section{Correspondence to} Torbjørn Soligard, Medical \& Scientific Department, International Olympic Committee, Château de Vidy, 1007 Lausanne, Switzerland; torbjorn.soligard@olympic.org

Received 19 April 2017 Revised 28 June 2017 Accepted 29 June 2017 Published Online First 29 July 2017
CrossMark

To cite: Soligard T,

Steffen K, Palmer D,

et al. Br J Sports Med

2017;51:1265-1271.

\section{ABSTRACT}

Objective To describe the pattern of injuries and

illnesses sustained during the Games of the XXXI

Olympiad, hosted by Rio de Janeiro from 5 to 21 August 2016.

Methods We recorded the daily incidence of athlete injuries and illnesses (1) through the reporting of all National Olympic Committee (NOC) medical teams and

(2) in the polyclinic and medical venues by the Rio 2016 medical staff.

Results In total, 11274 athletes (5089 women, 45\%; 6185 men, 55\%) from 207 NOCs participated in the study. NOC and Rio 2016 medical staff reported 1101 injuries and 651 illnesses, equalling 9.8 injuries and 5.4 illnesses per 100 athletes over the 17-day period. Altogether, $8 \%$ of the athletes incurred at least one injury and $5 \%$ at least one illness. The injury incidence was highest in BMX cycling (38\% of the athletes injured), boxing (30\%), mountain bike cycling (24\%), taekwondo (24\%), water polo (19\%) and rugby (19\%), and lowest in canoe slalom, rowing, shooting, archery, swimming, golf and table tennis (0\%-3\%). Of the 1101 injuries recorded, $40 \%$ and $20 \%$ were estimated to lead to $\geq 1$ and $>7$ days of absence from sport, respectively. Women suffered 40\% more illnesses than men. Illness was generally less common than injury, with the highest incidence recorded in diving (12\%), open-water marathon $(12 \%)$, sailing $(12 \%)$, canoe slalom $(11 \%)$, equestrian (11\%) and synchronised swimming (10\%). IIInesses were also less severe; $18 \%$ were expected to result in time loss. Of the illnesses, $47 \%$ affected the respiratory system and $21 \%$ the gastrointestinal system. The anticipated problem of infections in the Rio Olympic Games did not materialise, as the proportion of athletes with infectious diseases mirrored that of recent Olympic Games (3\%).

Conclusion Overall, $8 \%$ of the athletes incurred at least one injury during the Olympic Games, and 5\% an illness, which is slightly lower than in the Olympic Summer Games of 2008 and 2012.

\section{INTRODUCTION}

Routine physical activity elicits a number of health benefits, including a reduction in the risk of numerous chronic diseases and premature death. ${ }^{12}$ Compared with the general population, elite athletes seem to reap additional health benefits in the form of greater life expectancy and lower risk of disease and hospital admission. ${ }^{3-7}$ However, concomitantly, they run a higher risk of musculoskeletal disorders and long-term disability after the end of their careers. ${ }^{4-11}$

Systematic injury and illness surveillance is a prerequisite to effective protection of the health of the athletes. Epidemiological data contribute to better planning and provision of athlete healthcare and, importantly, inform the development of measures to prevent injury and illness. ${ }^{12} 13$

Some International Sports Federations or research institutes have set up injury and illness surveillance systems either longitudinally, over one or more seasons, or in certain main events. ${ }^{14-76}$ For Beijing 2008, the IOC developed the IOC injury surveillance system ${ }^{77}{ }^{78}$ which, to account for all health aspects, was expanded for Vancouver 2010 to also include illnesses. ${ }^{79}$ Since then, the surveillance system has been implemented in London $2012^{80}$ and Sochi 2014. ${ }^{81}$ In these Games, the injury and illness incidences have ranged from 9.6 to 14.0 injuries and from 7.2 to 8.9 illnesses per 100 athletes.

Our aim was to describe the incidence and characteristics of the sports injuries and illnesses occurring during the Rio 2016 Olympic Summer Games.

\section{METHODS}

We employed the IOC injury and illness surveillance system for multi-sport events in this prospective cohort study. ${ }^{77}$ We asked all National Olympic Committee (NOC) medical teams to report the daily occurrence (or non-occurrence) of athlete injuries and illnesses on a standardised medical report form (online appendix 1). Concurrently, we retrieved the same information on all athletes treated for injuries and illnesses in the polyclinic and all other medical venues operated by the Organizing Committee of the Olympic and Paralympic Games Rio 2016 (Rio 2016) medical staff. These data were collected through an electronic medical record system (GE Centricity Practice Solution), which was used for the first time in the Games.

We used the athlete accreditation number to control for duplicates resulting from athletes being treated for the same condition by both NOC and Rio 2016 medical staff. In such cases, we retained the NOC data. 


\section{Implementation}

Four months in advance, we informed the NOCs about the study by letter. The day before the opening of the Games, we organised an information meeting for all NOC medical staff, where we also distributed the daily injury and illness report forms, as well as an instructional booklet detailing the study protocol (online appendix 2).

Throughout the data collection, we actively followed up the NOCs comprising more than 10 participating athletes with frequent visits to address any questions and encourage continuous reporting during the games. We recorded the response rate of all the 207 NOCs.

\section{Definition of injury and illness}

We defined injuries and illnesses as new (ie, pre-existing, not fully rehabilitated conditions were not recorded) or recurring (athletes having returned to full participation after a previous condition) musculoskeletal complaints, concussions or other medical conditions (injuries) or illnesses incurred in competition or training during the Rio Olympic Games (5-21 August 2016) receiving medical attention, regardless of the consequences with respect to absence from competition or training. ${ }^{77}$ In cases where a single incident caused multiple injury types, we retained only the most severe diagnosis, as determined by our research team based on all available clinical data, for analysis. ${ }^{80}$ Severe injuries and illnesses were defined as injuries or illnesses estimated to lead to absence from training or competition of more than 1 week.

\section{Injury and illness report form}

Our NOC injury and illness report form (online appendix 1) was identical to the one we used in the Vancouver 2010, London 2012 and Sochi 2014 Olympic Games. ${ }^{79-81}$ With respect to injuries, we recorded the following data: accreditation number, sport and event, whether the injury occurred in competition or training, date and time, body part, type, cause and estimated time lost from competition or training. We recorded data on illnesses in a similar fashion: accreditation number, sport and event, date, affected system, main symptom(s), cause and estimated time loss.
We provided instructions and examples on how to complete the form correctly in the instructional booklet. Furthermore, we distributed the injury and illness report form in English, French, Arabic, Chinese, German, Japanese, Russian and Spanish.

\section{Confidentiality and ethical approval}

We used the athlete accreditation number to query the IOC athlete database for the age, gender and nationality of the injured or ill athlete. We treated all information confidentially and deidentified our database after the Games.

The study was reviewed by the Medical Research Ethics Committee of the South-Eastern Norway Regional Health Authority (2011/388).

\section{Data analysis}

We calculated the summary measures of injury and illness incidences $(i)$ according to the formula $i=n / e$, where $n$ is the number of injuries or illnesses in competition, training or in total during the study period and $e$ is the respective number of exposed (participating) athletes, with incidence proportions presented as injuries/illnesses per 100 athletes. We also calculated the summary measures of injury and illnesses per 1000 athlete-days, where athlete-days correspond to the total number of athletes multiplied by 17 days. We calculated CIs of the risk ratio (RR) of the number of injuries or illnesses between two groups by a simple Poisson model, assuming constant hazard per group. We present injury and illness incidences as means and RRs with 95\% CIs. We regarded two-tailed $\mathrm{p}$ values $<0.05$ as significant.

\section{RESULTS}

In total, 11274 athletes took part in the Rio Olympic Games. Of these, 5089 were women (45\%) and 6185 men (55\%). There were eight double-starters, meaning athletes who participated in two different sports, giving a total of 11289 athlete exposures to injury or illness.

Throughout the 17 days of the Rio Games, the 207 NOCs submitted 1590 of a maximum of 3519 forms (45\%; 97 countries did not submit any data) (table 1). The response rate of

Table 1 Response rates, injuries and illnesses in NOCs of different sizes (measured by number of athletes)

\begin{tabular}{|c|c|c|c|c|c|}
\hline & $<10$ & $10-49$ & $50-99$ & $>99$ & All \\
\hline NOCs (athletes) & $93(502)$ & $56(1341)$ & $24(1635)$ & 34 (7796) & $207\left(11274^{*}\right.$ \\
\hline $\begin{array}{l}\text { Injuries (injuries per } 100 \\
\text { athletes) }\end{array}$ & $61(12.2)$ & $191(14.2)$ & $139(8.5)$ & $679(8.7)$ & $1101+(9.8)$ \\
\hline $\begin{array}{l}\text { Illnesses (illnesses per } 100 \\
\text { athletes) }\end{array}$ & $27(5.4)$ & $90(6.7)$ & $51(3.1)$ & $429(5.5)$ & $613+(5.4)$ \\
\hline Report forms submitted (\%) & $151(10.0)$ & $584(61.3)$ & $337(82.6)$ & $518(89.6)$ & $1590(45.2)$ \\
\hline \multicolumn{6}{|l|}{$\begin{array}{l}\text { Recorded by both NOC and } \\
\text { Rio } 2016\end{array}$} \\
\hline Injuries (\%) & $2(3.2)$ & $12(6.3)$ & $16(11.4)$ & $36(5.3)$ & $66 \ddagger(6.0)$ \\
\hline Illnesses (\%) & - & $1(1.0)$ & $2(3.8)$ & $7(1.5)$ & $10 \ddagger(1.5)$ \\
\hline \multicolumn{6}{|l|}{ Recorded only by NOCs } \\
\hline Injuries (\%) & $12(19.7)$ & $120(62.8)$ & $72(51.4)$ & $422(62.2)$ & $654 \ddagger(59.3)$ \\
\hline Illnesses (\%) & $6(22.2)$ & $57(63.3)$ & $34(66.6)$ & $313(73.0)$ & $426 \ddagger(69.5)$ \\
\hline \multicolumn{6}{|l|}{ Recorded only by Rio 2016} \\
\hline Injuries (\%) & $47(75.8)$ & $53(27.6)$ & $48(34.3)$ & $145(21.2)$ & $293 \ddagger(26.6)$ \\
\hline Illnesses (\%) & $21(77.8)$ & $24(24.2)$ & $13(24.5)$ & $37(8.1)$ & $95 \ddagger(14.5)$ \\
\hline
\end{tabular}

*15 double-starters excluded.

†NOC is missing for 31 injuries and 16 illnesses.

‡Test for duplicate not possible for 88 injuries and 82 illnesses where accreditation number was missing.

NOC, National Olympic Committee. 


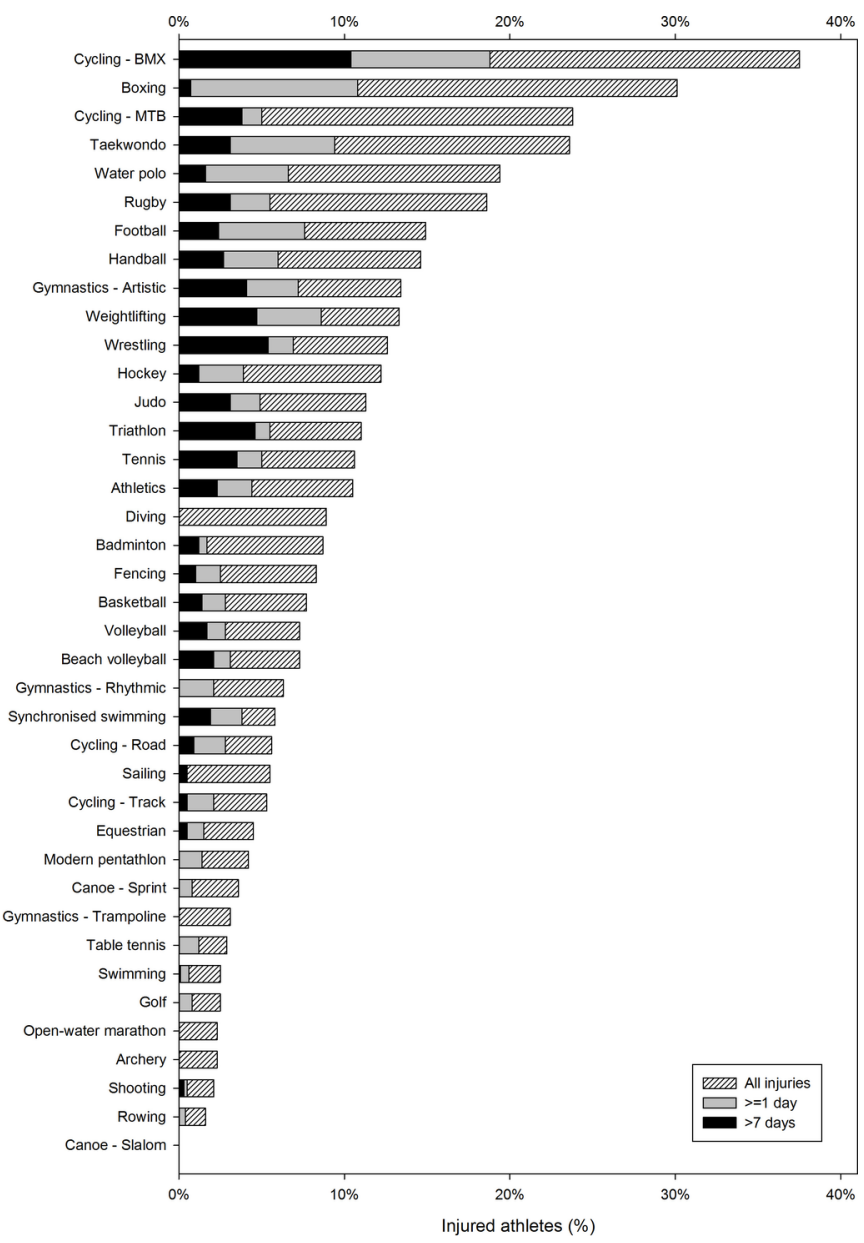

Figure 1 Proportions of athletes (\%) in each sport with injury, injury with estimated time loss $\geq 1$ day, and injury with estimated time loss $>7$ days.

the 114 NOCs with $>10$ participating athletes (accounting for $10772 / 96 \%$ of all the athletes) was 74\% (1439 of 1938 forms).

\section{Injuries overall, by sport and gender}

We recorded a total of 1101 injuries, equalling 9.8 injuries (95\% CI 9.2 to 10.3 ) per 100 participating athletes. This corresponds to 5.7 injuries per 1000 athlete-days. On average, $8 \%$ $(n=931)$ of the athletes sustained at least one injury. In addition, there were 70 and 10 athletes with two and three injuries each, respectively.

Figure 1 shows the incidence proportion of injured athletes in each sport (additional details are available in online appendix $3)$. The incidence of injury was highest in BMX cycling (37.5 injuries (95\% CI 20.2 to 54.8$)$ per 100 athletes), boxing (30.1 (23.7-36.4)), mountain bike cycling (23.8 (13.1-34.4)), taekwondo (23.6 (15.2-32.1)), water polo (19.4 (14.0-24.8)) and rugby (18.6 (13.6-23.5)), and lowest in canoe slalom, rowing, shooting, archery, swimming, golf and table tennis (ranging from 0 to 3 injuries per 100 athletes).

The injury incidences for women (9.3 injuries (95\% CI 8.4 to 10.1$)$ per 100 athletes) and men (9.4 (8.6-10.1), $\mathrm{RR}=0.99$ (0.87-1.11)) were nearly identical (online appendix 4). However, women were at significantly higher risk of injury in sailing $(\mathrm{RR}=5.33(1.78-15.93))$, shooting ( $R \mathrm{R}=5.14 \quad(1.67-$ $15.78)$ ) and mountain bike cycling $(\mathrm{RR}=3.61(1.37-9.50))$.
Box 1 Information on the 221 severe injuries (estimated absence $>7$ days), with the sports with the highest numbers in brackets (unadjusted for athlete exposures in each sport).

- 65 muscle strains (33 in athletics, six in football, six in weightlifting)

- 57 ligament sprains/ruptures (eight in wrestling, six in athletics, six in judo, five in artistic gymnastics, five in weightlifting)

- 24 fractures (three in hockey, three in rugby, two in boxing, two in artistic gymnastics, two in mountain bike cycling, two in road cycling, two in water polo)

- 15 dislocations or subluxations (four in wrestling, three in judo, two in boxing)

- 12 lesions of meniscus or cartilage

- nine concussions (out of 12 in total: seven in boxing, two in rugby, one each in BMX cycling, mountain bike cycling, and handball)

- seven stress fractures (three in athletics, two in tennis, one each in boxing and triathlon)

- six tendon ruptures

- five contusions, haematomas or bruises

- five lacerations, abrasions or other skin lesions (three in boxing, two in triathlon)

- four nerve or spinal cord injuries

- four tendinopathies (three in athletics)

- two arthritis, synovitis or bursitis injuries

- two impingements

- two 'other bone injuries

Injury type was missing for two of the severe injuries.

There was no statistical difference in the incidence of injury between the NOCs that did not report any NOC data (ie, Rio 2016 data only) and the NOCs that reported data (7.9 vs 9.8 injuries per 100 athletes; $\mathrm{RR}=1.24(0.72-2.14)$ ).

\section{Severity of injuries}

While almost two thirds of the injuries were estimated to result in no time loss from sport $(n=662,60 \%), 40 \%$ of the injuries $(n=438)$ were expected to prevent the athlete from participating in competition or training (online appendix 3). Figure 1 shows the incidence of injuries estimated to lead to $\geq 1$ day and $>7$ days of absence in each sport. It was estimated that $14 \%$ of the injuries $(n=153)$ would result in an absence from sports from 1 to 3 days, $6 \%(n=64)$ in an absence from 4 to 7 days, $10 \%(n=106)$ in an absence from 8 to 28 days and $10 \%(n=115)$ in an absence for more than 28 days. Information on severity was missing for one injury.

A total of 221 injuries (20\%) were classified as severe, with an estimated absence from training or competition of more than 1 week (box 1 , online appendix 3 ).

\section{Location and type of injuries}

The most commonly injured anatomical locations were the knee $(n=130)$, thigh $(n=108)$, ankle $(n=103)$, face $(n=94)$ and lower leg $(n=90)$. The most common injury types were sprain/ligament rupture $(n=187)$, contusion/haematoma/bruise $(n=178)$, strain/ muscle rupture/tear $(n=168)$, laceration/abrasion/skin lesion $(n=152)$ and tendinosis/tendinopathy $(n=112)$. The distribution 
of injury locations and injury types per sport are presented in online appendices 5 and 6 , respectively.

\section{Causes, mechanisms and onset of injury}

While $71 \%(n=781)$ of the injuries were reported to occur acutely, 27\% ( $n=301)$ were reported to be caused by overuse (information missing for 19 injuries). The three most commonly reported injury causes/mechanisms were contact with another athlete (28\%), non-contact trauma (21\%) and overuse with gradual onset (19\%). The distribution of injury causes/mechanisms in each sport is detailed in online appendix 7. Of all overuse injuries (gradual and sudden onset) occurring in the Games, $72 \%$ were recorded with no estimated absence from competition or training.

In terms of onset, $59 \%$ of the injuries were sustained in competition (5.8 (5.3-6.2) injuries per 100 athletes) and 37\% during training (3.6 (3.2-3.9) injuries per 100 athletes; $R R=1.61$ (1.42-1.82)) (information on training/competition was missing for 45 injuries; online appendix 3). However, when analysing only the severe injuries, those estimated to result in at least 7 days of absence, the difference was greater $(R R=2.22(1.69-2.96))$.

Injuries in training and in competition differed significantly in characteristics (location, type, mechanism and subsequent time loss from sport) and in terms of incidence in different sports (online appendix 3). The injury incidence was higher in competition than in training in boxing $(\mathrm{RR}=7.50(3.88-14.51))$, tennis $(\mathrm{RR}=6.00 \quad(1.77-20.37))$, hockey $(\mathrm{RR}=5.71 \quad(2.56-12.76))$, rugby $(\mathrm{RR}=5.38 \quad(2.53-11.43))$, handball $(\mathrm{RR}=3.90 \quad(1.95-$ $7.81))$, football $(\mathrm{RR}=3.63(2.08-6.31))$, water polo $(\mathrm{RR}=3.56$ (1.70-7.45)), BMX cycling $(\mathrm{RR}=3.50(1.15-10.63))$, basketball $(\mathrm{RR}=3.40(1.25-9.22))$, fencing $(\mathrm{RR}=3.25(1.06-9.97))$ and judo $(R R=2.91(1.47-5.77))$. Swimming was the only sport in which the incidence of injury was significantly higher in training than in competition $(\mathrm{RR}=0.29(0.11-0.80))$.

\section{Illnesses overall, by gender, sport and severity}

Among the 11289 exposed athletes, a total of 613 illnesses were reported, resulting in 5.4 illnesses (95\% CI 5.0 to 5.9) per 100 athletes. This corresponds to 3.2 illnesses per 1000 athlete-days. On average, $5 \%(\mathrm{n}=587)$ of the athletes incurred an illness, as there were 26 athletes with two illnesses each. Women $(5.7$ illnesses (5.0-6.3) per 100 athletes) were at significantly higher risk of contracting an illness than men (4.0 (3.5-4.5), RR=1.41 (1.19-1.67)).

Figure 2 shows the incidence proportion of ill athletes in each sport (additional details are available in online appendix 3). Diving was the sport with the highest illness incidence (11.9 illnesses (95\% CI 6.0 to 17.7$)$ per 100 athletes), followed by open-water marathon (11.8 (2.4-21.2)), sailing (11.8 (8.4-15.3)), canoe slalom (10.8 (3.8-17.9)), equestrian (10.5 (6.0-15.0)) and synchronised swimming (9.6 (3.7-15.6)). The illness incidence was low in a number of sports, with the lowest incidences recorded in trampoline and artistic gymnastics, golf and handball (ranging from 0 to 2 illnesses per 100 athletes).

One in five illnesses $(n=113,18 \%)$ were expected to result in absence from training or competition. Of these, two illnesses $(0.3 \%)$ were expected to result in an estimated time loss of more than 7 days (chickenpox and conjunctivitis).

\section{Affected system, main symptoms and causes of illness}

A total of 292 illnesses (47\%) affected the respiratory system. The second, third and fourth most frequently affected systems were the digestive system $(n=131,21 \%, 1 \%$ of the athletes affected),

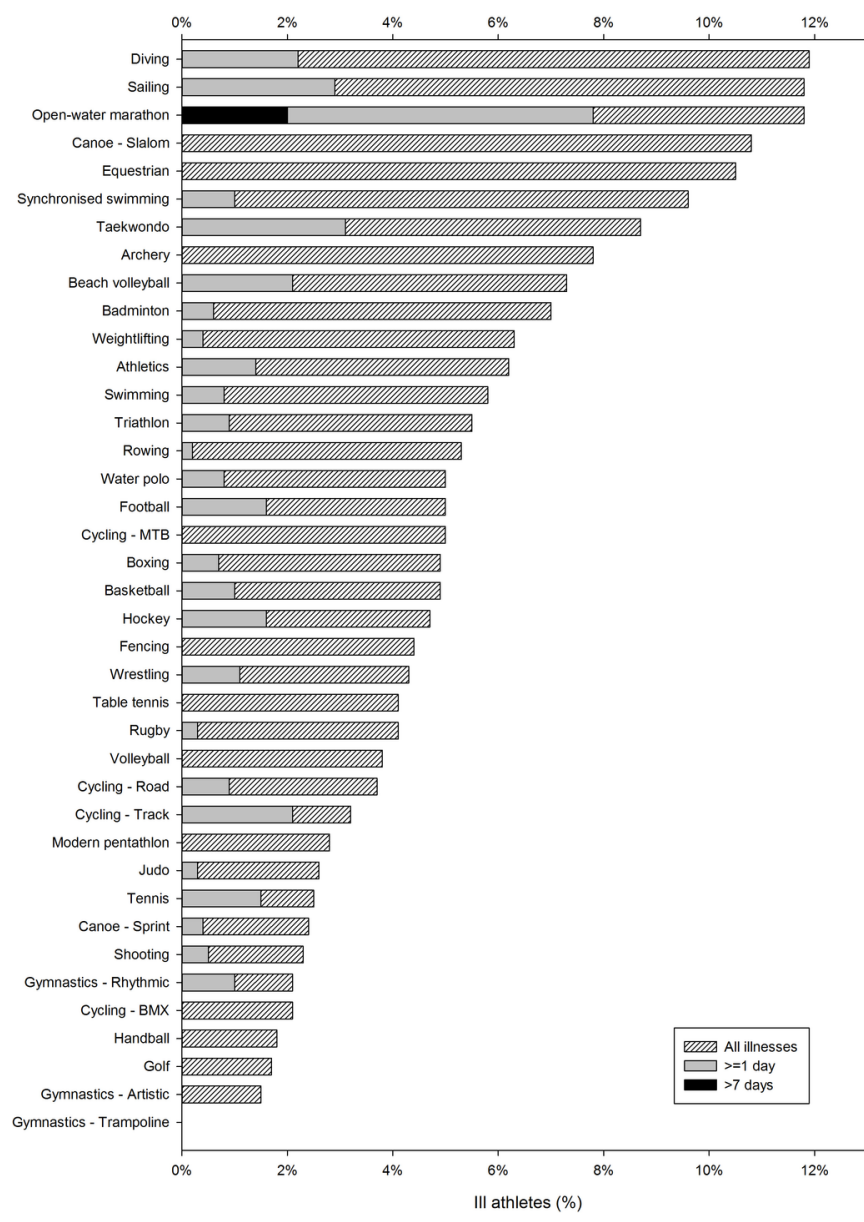

Figure 2 Proportions of athletes (\%) in each sport with illness, illness with estimated time loss $\geq 1$ day and illness with estimated time loss $>7$ days.

skin and subcutaneous tissue $(\mathrm{n}=53,9 \%)$, nervous system $(n=38,6 \%)$ and genitourinary system $(n=27,4 \%)$, respectively. Infection was the most common cause of illness $(n=346,56 \%$ of the illnesses; $3 \%$ of the athletes incurred an infection). Of the 292 respiratory illnesses, $223(76 \%)$ were caused by an infection. The distribution of affected systems, main symptoms and causes of illness per sport are presented in online appendices 8 , 9 and 10, respectively.

\section{Data sources, and injuries and illnesses per NOC size}

Only $6 \%$ of the injuries and $2 \%$ of the illnesses were captured by both the NOCs and the Rio 2016 staff. While 59\% of the injuries and $70 \%$ of the illnesses were recorded solely by the NOCs, $27 \%$ and $15 \%$ of the injuries and illnesses, respectively, were recorded only by the Rio 2016 staff.

Whereas the majority of injured and ill athletes from the larger NOCs were seen internally by the NOC medical staff, athletes from small NOCs were to a greater extent relying on diagnosis and treatment from the Rio 2016 medical staff (table 1).

There was also an inverse relationship between NOC size (measured in number of participating athletes) and the risk injuries, with athletes from smaller NOCs suffering more injuries (NOCs with <10 athletes: 12.2 (9.1-15.2) injuries per 100 athletes versus NOCs with $>99$ athletes: 8.7 (8.1-9.4) injuries per 100 athletes, injury $\mathrm{RR}=1.40(1.07-1.81))$. 


\section{DISCUSSION}

The aim of the present paper was to describe and analyse the incidence and characteristics of the sports injuries and illnesses in the Rio 2016 Olympic Games. The main findings of this 17 -day-long prospective cohort study were that $8 \%$ and $5 \%$ of all the 11274 athletes suffered from at least one injury or illness, with overall incidences of 9.8 injuries and 5.4 illnesses per 100 athletes, respectively.

Injury incidences varied from high to low across sports, with the highest incidences found in BMX cycling, boxing, mountain bike cycling, taekwondo, water polo and rugby. Illness incidences were generally lower, with the highest incidences seen in diving, open-water marathon, sailing, canoe slalom, equestrian and synchronised swimming.

\section{Injuries in the Olympic sports}

The incidence of injury in the Rio Games (8\%) was lower than those in Beijing 2008 (10\%), ${ }^{78}$ Vancouver $2010(11 \%),{ }^{79}$ London $2012(11 \%)^{80}$ and Sochi $2014(12 \%) .{ }^{81}$ It was also lower than the injury incidences reported from recent Paralympic Games. ${ }^{33-36} 38$

When comparing each sport in Rio 2016 with Beijing 2008, higher injury incidences were found in diving ( $9 \%$ vs $2 \%$ of the athletes injured), water polo (19\% vs $10 \%)$, boxing (30\% vs $15 \%)$, fencing ( $8 \%$ vs $2 \%$ ) and sailing ( $6 \%$ vs $1 \%$ ), while the injury incidences were lower in basketball ( $8 \%$ vs 13\%), football (15\% vs $32 \%)$ and hockey (12\% vs $20 \%)$.

Likewise, when doing a similar comparison with London 2012, the injury incidences in Rio were higher in boxing $(30 \%$ vs $9 \%$ ) but lower in athletics (11\% vs $18 \%)$, football (15\% vs $35 \%)$, handball ( $15 \%$ vs $22 \%)$, sailing ( $6 \%$ vs $15 \%)$, swimming ( $3 \%$ vs $5 \%)$ and taekwondo ( $24 \%$ vs $39 \%)$.

Some sports have collected and published data on injury incidences in their world championships or other main events. The incidence of football injury in Rio 2016 was similar to those in the 2014 World Cup, ${ }^{20} 2004^{29}$ and $2008^{31}$ European championships, but half of that in the 2010 World Cup. ${ }^{19}$ In athletics, as well as in diving, swimming and synchronised swimming, the injury incidences in Rio were similar to those reported from recent world championships. ${ }^{40-47}$ In contrast, the Rio injury incidences in open-water marathon and water polo were lower and higher, respectively, than previously reported from the aquatics world championships. ${ }^{46} 47$ In rugby sevens, the injury incidence in Rio was less than half than previously found in the Rugby Sevens World Cup and World Series. ${ }^{23}$ Similarly, the proportions of injured athletes in the beach volleyball tournaments in the three latest summer Olympic Games constitute about one third of that reported earlier in the beach volleyball world championships. ${ }^{14}$ In handball, the incidence of injuries in Rio was about half of that found in the men's world championship in $2015 .^{64}$ Interestingly, and in contrast, the BMX cycling injury incidence in Rio was about six times higher than that documented in the 1989 BMX European championships. ${ }^{70}$

A change in injury incidence can be the result of changes in the composition of the Olympic Games programme (eg, two new sports in Rio), environmental factors, venue or track design, competition rules or changes in equipment. Recorded injury frequencies are also likely to be influenced by the response rate and reporting accuracy by the NOC and organising committee medical staff. However, our analysis comparing the injury incidences of the NOCs that reported data and those that did not (other than the data recorded by the Rio 2016 staff) indicated no significant difference between the two. In addition, in Rio 2016, a new electronic medical record was used for the first time by the organising committee medical staff. Also, incidence differences (lower or higher) may simply be the result of a natural variability of athletes' exposure to risk, an observation that emphasises the value of ongoing surveillance to monitor trends over time, for example, the effect of venue design, rule or equipment changes in the period between major sports events.

\section{Severity of injuries}

In major sports events, like the Olympic Games, injuries or illnesses of even minor severity with or without time loss have the potential to be both participation limiting and performance inhibiting, and thus prevent athletes from possibly fulfilling their potential and reaching their life-time achievement. In the Rio Games, $40 \%$ of the injuries were estimated to result in time loss from competition or training of at least 1 day. This places Rio 2016 between London 2012 and Beijing 2008 , in which the equivalent numbers were $35 \%$ and $50 \%$, respectively. In contrast, athletes in Rio incurred more injuries of higher severity (20\% of the injuries estimated to result in absence greater than 7 days) than the athletes in London 2012 and Beijing 2008 (both 13\%).

The sports with the highest incidences of injuries entailing a prolonged absence from training or competition ( $>7$ days) were BMX cycling (10\% of the athletes), wrestling (5\%), weightlifting $(5 \%)$ and triathlon $(5 \%)$, which is similar to the data from the London Games.

\section{Causes, mechanisms and onset of injury}

The causes, mechanisms and circumstances of injuries in competition and training differed significantly between the different sports. Overall, the distribution of injuries in competition and training (59\% vs 37\%) was similar to that of London 2012, ${ }^{80}$ the 2009 and 2013 Aquatics World Championships, ${ }^{46} 47$ the 2010 men's Football World Cup, ${ }^{19}$ and the 2011 Athletics World Championships, ${ }^{42}$ but not Beijing 2008, ${ }^{78}$ the 2007 or 2009 Athletics World Championships, ${ }^{40} 41$ or the 2015 men's Handball World Championships, ${ }^{64}$ where the incidence of competition injuries was higher. In Rio 2016, the majority of injuries were reported to be acute, whereas overuse injuries with either a gradual or sudden onset accounted for a quarter of the injuries. Although similar distributions were reported from London 2012 and Beijing 2008, these numbers should be interpreted with caution, due to the limitations in the recording of overuse injuries in the current methodology. ${ }^{82-86}$

\section{Illness risk during the Olympics}

In the lead up to the Rio Games, there were concerns about the risk of gastroenteritis and other infections from various water-borne viruses and bacteria, as well as the mosquito-borne Zika virus, with some calling for the Games to be cancelled. ${ }^{87}$ However, the overall proportion of athletes with illness in the Rio Games (5\%) was actually lower than those reported from London $2012(7 \%),{ }^{80}$ Vancouver $2010(7 \%)^{79}$ and Sochi 2014 $(8 \%) .{ }^{81}$ While the majority of illnesses in Rio (56\%) were caused by an infection, the proportion of athletes contracting an infection (3\%) was identical to London 2012 (3\%) and lower than Sochi 2014 (5\%). Similarly, the incidence of digestive system illness (1\%) was identical to London 2012 (also 1\%). In terms of the Zika virus, no cases were reported among either athletes or the general population during the Olympic Games in Rio. ${ }^{88}$

As in previous Olympic Games, ${ }^{79-81}$ female athletes contracted more illnesses than male athletes. The same disproportion has previously been reported in the 2009 Athletics ${ }^{41}$ and Aquatics ${ }^{46}$ 
World Championships, but not in the 2011 Athletics $^{42}$ or 2013 Aquatics ${ }^{47}$ World Championships, in the 1994-2009 US Open Tennis Championships, ${ }^{89}$ or in the Winter or Summer Paralympic Games. $^{37} 39$

\section{Methodological considerations}

In studies on sports injury, it is usually recommended to express incidences using a measure of time exposed to risk as the denominator. ${ }^{35-379091}$ However, considering the inherent complexity and size of the Olympic Games, this was not feasible in the present study. Instead, we expressed the injuries or illnesses by means of absolute risk: the number of new cases per 100 registered athletes (incidence proportion). This approach erroneously assumes that the frequencies and lengths of exposure are identical in all sports and that the number of athletes at risk in each NOC is constant throughout the Games. Interpretation of differences in injury incidences or patterns should therefore be made with caution.

In the current study, we defined injuries and illnesses as new or recurring injuries or illnesses receiving medical attention, regardless of the consequences with respect to absence from competition or training. By using such a definition, less serious injuries may be overlooked, since such injuries do not always require medical attention. ${ }^{92} 93$ Nonetheless, our results show that the majority of reported injuries were not estimated to involve any absence from the sport. Also, in the Olympic Games, all athletes can get healthcare through the athletes' village polyclinic and the venue medical clinics. However, the availability, size and quality of the NOCs' own medical teams vary among countries, meaning that not all athletes benefit from identical healthcare, which may bias the injury and illness recording.

Throughout the 17 days of data collection in the Olympic Games, we collected $45 \%$ of all the NOC injury and illness report forms. If including only the NOCs which we actively followed up (those with more than 10 athletes), as done in previous Olympic Games, the response rate was 74\%, which is lower than in previous Games (99.7\% in Sochi; $96 \%$ in London). It is difficult to speculate as to what the potential causes are. In the future, transitioning to an electronic data collection system, similar to that used in the Paralympics, ${ }^{35}$ may help to improve the response rate among the NOCs, as well as the accuracy of the data.

A mere $6 \%$ of the injuries and $2 \%$ of the illnesses were captured by both the NOC and the Rio 2016 medical personnel, underlining the importance of both recorder groups. Our study also shows that in particular athletes from smaller NOCs benefit from diagnosis and treatment from the local organising committee's medical staff, whereas the majority of athletes from larger NOCs are seen by their own NOC medical staff. More importantly, we once again identified an inverse relationship between NOC size and the risk of health problems, with athletes from the smallest NOCs experiencing significantly more injuries compared with the largest NOCs. It is difficult not to see this finding in light of distinct differences in resources available to the NOC. Large delegations usually come from countries with well-developed exercise physiology and sports medicine communities and are generally able to offer their athletes more comprehensive healthcare and closer medical follow-up both in the lead up to and during the Games, potentially giving them a competitive advantage.

\section{Practical implications}

The continuously accumulating evidence that injuries and illnesses vary substantially between sports demonstrates the need for tailoring preventive measures to the specific context of each sport. Sport bodies such as the IOC, International Paralympic Committee, International Sports Federations (IFs) and NOCs have the responsibility to protect the health of their athletes. The Olympic Movement Medical Code encourages all stakeholders to take measures to ensure that sport is practised with minimal risks of physical injury and illness or psychological harm. ${ }^{94}$ For IFs, a critical component of this responsibility is the implementation of a scientifically sound injury and illness surveillance system in all major events. Some sports federations have put increasing effort into working systematically and scientifically to protect their athletes' health. ${ }^{15-20} 22-47$ 49-61 68 We encourage other IFs and sports organisations to follow their example.

\section{CONCLUSION}

In summary, $8 \%$ of the athletes had a reported medical encounter for a new or recurrent injury and 5\% an illness during the Rio Olympic Summer Games. The incidences and characteristics of injuries and illnesses in training and competition varied substantially between sports and gender.

\section{What are the findings?}

- Overall, $8 \%$ and $5 \%$ of the athletes incurred at least one injury or illness, respectively, during the Rio 2016 Olympic Games.

- BMX cycling (38\%), boxing (30\%), mountain bike cycling $(24 \%)$, taekwondo $(24 \%)$, water polo $(19 \%)$ and rugby $(19 \%)$ were the sports with the highest incidence of injury.

- Diving (12\%), open-water marathon (12\%), sailing (12\%), canoe slalom (11\%), equestrian (11\%) and synchronised swimming $(10 \%)$ were the sports with the highest illness incidence.

- The rate of infectious diseases in Rio was low and consistent with previous Olympic Games.

How might it impact on clinical practice in the near future?

These injury and illness data can help inform policy and planning of major multi-sport events (eg, Asian Games, Commonwealth Games, Pan American Games, European Games).

- These data can directly inform the focus and development of injury prevention measures in sport.

\section{Author affiliations}

${ }^{1}$ Medical and Scientific Department, International Olympic Committee, Lausanne, Switzerland

${ }^{2}$ Sport Injury Prevention Research Centre, Faculty of Kinesiology, University of Calgary, Calgary, Alberta, Canada

${ }^{3}$ Oslo Sports Trauma Research Center, Department of Sports Medicine, Norwegian School of Sport Sciences, Oslo, Norway

${ }^{4}$ School of Applied Sciences, Edinburgh Napier University, Edinburgh, UK

${ }^{5}$ Division of Rheumatology, Orthopaedics and Dermatology, School of Medicine, University of Nottingham, Nottingham, UK

${ }^{6}$ Department of Sports Medicine, Aspetar Qatar Orthopedics and Sports Medicine Hospital, Doha, Qatar

${ }^{7}$ Department of Physical Therapy, University of Massachusetts Lowell, Lowell, Massachusetts, USA

${ }^{8}$ Department of Neurology, Spine Unit, Schulthess Clinic, Zurich, Switzerland ${ }^{9}$ Institute of Sport and Health, University College Dublin, Dublin, Ireland 
${ }^{10}$ Fédération International de Natation (FINA), Lausanne, Switzerland

${ }^{11}$ Masters and Doctoral Programs in Physical Therapy, Universidade Cidade de São Paulo, São Paulo, Brazil

${ }^{12} \mathrm{GE}$ Healthcare, Moscow, Russia

${ }^{13}$ Department of Orthopaedic Surgery, University of Oslo, Oslo, Norway

Acknowledgements The authors would like to acknowledge the contribution and support of the Rio 2016 staff throughout the different stages of this study. The authors also sincerely thank all the NOC medical staff contributing to the data collection: Dr Loughraieb Mok Amine (ALG), Dr Maria Stella Cristiano (ANG), Dr Hugo Rodriques Papini (ARG), Dr Davit Mosinyan (ARM), Dr Carolyn Broderick (AUS), Dr Alfred Engel (AUT), Dr Guliyeva Ludmila (AZE), Dr Virgil Rene Best (BAR), Dr Johan Bellemans (BEL), Dr Henadzi Zaharodny (BLR), Dr Roberto Nahon (BRA), Dr André Pedrinelli (BRA), Dr Stefan Strugarov (BUL), Dr Bob McCormack (CAN), Dr Joshua Ferguson (CAN), Dr Jaques Ngouonimba Goulou (CGO), Dr Alejandro Orizola (CHI), Dr Minhao Xie (CHN), Dr Ngiebe Mubiala (COD), Dr Juan Carlos Quiceno (COL), Dr Karen Nuit Cifuentes Rodríguez (COL), Dr Humberto Evora (CPV), Dr Max Moreira (CRC), Dr Damir Jemmendzic (CRO), Dr Dinko Pivvalica (CRO), Dr Miroslav Smerdej (CRO), Dr Pablo Castillo Diaz (CUB), Dr Constantinos Schizas (CYP), Dr Petr Sikora (CZE), Dr Lars Juel Andersen (DEN), Dr Francis Sanchez (DOM), Dr Pablo Sarmiento Panchana (ECU), Dr Haile Ghirmasion (ERI), Dr Rosario Urena Duran (ESP), Dr Mihkel Mardua (EST), Dr Ayalew Tilahun Beshahe (ETH), Dr Maarit Valtonen (FIN), Dr Philippe Le Van (FRA), Dr Fabrice Bryand (FRA), Dr Niall Elliott (GBR), Dr Mike Rossiter (GBR), Dr Zurab Kakhabrishvili (GEO), Dr Bernd Wolfarth (GER), Dr Odysseas Paxinos (GRE), Dr Georgios Marinos (GRE), Dr Greg Varigos (GRN), Dr Luis Cruz (GUM), Dr Mukkuaka Oda (HAI), Dr Julian Wai Chang (HKG), Dr Eva Vinalti (HON), Dr Peter Barlogh (HUN), Dr Antonius Andi Kurniawan (INA), Dr Leane Suniar Manuruna (INA), Dr Pawanddeep Singh Kohli (IND), Dr Gholamreza Norouzi (IRI), Dr Rod McLoughlin (IRL), Dr Ghaleb Abbas Salih (IRQ), Dr Örnolfur Valoimarsson (ISL), Dr Lubov Galitskaya (ISR), Dr Antonio Spataro (ITA), Dr Derrick McDowell (JAM), Dr Kohei Nakajima (JPN), Dr Tomohiro Manabe (JPN), Dr Shuichi Nakayama (JPN), Dr Hiroshi Takagi (JPN), Dr Serikkazy Mazenhov (KAZ), Dr Natalia Kudashova (KAZ), Dr Elena Galtis (KAZ), Dr Daniel Langat (KEN), Dr Baktygul Alisheva (KGZ), Dr Jungjoong Yoon (KOR), Dr Liga Circule (LAT), Dr Axel Urhausen (LIE), Dr Dalius Barkauskas (LTU), Dr Axel Urhausen (LUX), Dr Christian Nührenbörger (LUX), Dr Semmar Sahar (MAR), Dr Arshad Bin Puji (MAS), Dr Balmus Dorin (MDA), Dr Viridiana Silva Quiroz (MEX), Dr Chuluun Nasanbat (MGL), Dr Bayartuya Bayarsaikhan (MGL), Dr Licienne Attard (MLT), Dr Predrag Dabovic (MNE), Dr Flezer Tomadote (MOZ), Dr Jürgen Hofmann (NAM), Dr Aniya-Mart Kruger (NAM), Dr Cees-Rein van den Hoogenband (NED), Dr Sarub Shrestha (NEP), Dr Abdulkadir Mu'azu (NGR), Dr Thomas Torgalsen (NOR), Dr Lars Haugvad (NOR), Dr Anne Froholdt (NOR), Dr Bruce Hamilton (NZL), Dr Mark Fulcher (NZL), Dr Victor Carpio Quintana (PER), Dr Bernie Amof (PNG), Dr Hubert Krysztofiak (POL), Dr Maria Joao Cascascais (POR), Dr Kim Yumi (PRK), Dr Rebecca Rodriquez (PUR), Dr Juan Manuel Alonso (QAT), Dr Carlo Bagutti (ROT), Dr Tanase Dan (ROU), Dr Kevin Subban (RSA), Dr Andrej Sereda (RUS), Dr Seydina Omar Diagne (SEN), Dr Darren Leong (SIN), Dr Matjaz Vogrin (SLO), Dr Martin Zorko (SLO), Dr Katja Azman Juvan (SLO), Dr Dragan Radovanovic (SRB), Dr Goran Vasic (SRB), Dr Patrick Noack (SUI), Dr Branislav Delej (SVK), Dr Per Andersson (SWE), Dr Fredrik Bergström (SWE), Dr Mats Börjesson (SWE), Dr Nassoro Matuzya (TAN), Dr Hilary Meechai Inwood (THA), Dr Lin Yzn Chou (TPE), Dr Tonya Welch (TTO), Dr Ayachi Saida (TUN), Dr Tugba Kocahan (TUR), Dr Hassan Kamal (TUR), Dr Abdulhameed Alattar (UAE), Dr Robert Zavuga (UGA), Dr Oleksandr Varvinskyi (UKR), Dr Daniel Zarrillo (URU), Dr Bill Moreau (USA), Dr Svetlana Suyatskaya (UZB), Dr Joze German Medina (VEN), Dr Phu Nguyen Van (VIE), Dr Mulenga Davie (ZAM), Dr Austin Jeans (ZIM), Dr Dorothy Masawi (ZIM) and Dr Nicholas Munyonga (ZIM).

Contributors All authors contributed to the study conception and design, data collection and interpretation. TS analysed the data and drafted the paper. All authors provided revisions and contributed to the final manuscript. TS is the guarantor.

Funding The study was funded by the International Olympic Committee.

Competing interests None declared.

Ethics approval The study was reviewed by the Medical Research Ethics Committee of the South-Eastern Norway Regional Health Authority (2011/388).

Provenance and peer review Not commissioned; externally peer reviewed.

(c) Article author(s) (or their employer(s) unless otherwise stated in the text of the article) 2017. All rights reserved. No commercial use is permitted unless otherwise expressly granted.

\section{REFERENCES}

1 World Health Organization. Global recommendations on physical activity for health 2010 http://www.who.int/dietphysicalactivity/publications/9789241599979/en/.

2 Centers for Disease Control and Prevention. Physical activity and health - the benefits of physical activity. http://www.cdc.gov/physicalactivity/everyone/health/index.html

3 Sarna S, Sahi T, Koskenvuo M, et al. Increased life expectancy of world class male Athletes. Med Sci Sports Exerc 1993;25:237-244.
4 Kujala UM, Sarna S, Kaprio J, et al. Hospital care in later life among former world-class finnish Athletes. JAMA 1996:276:216-20.

5 Teramoto M, Bungum TJ. Mortality and longevity of elite Athletes. J Sci Med Sport 2010;13:410-6.

6 Clarke PM, Walter SJ, Hayen A, et al. Survival of the fittest: retrospective cohort study of the longevity of Olympic medallists in the modern era. BMJ 2012;345:e8308.

7 Zwiers R, Zantvoord FW, Engelaer FM, et al. Mortality in Former Olympic Athletes: retrospective cohort analysis. BMJ 2012;345:e7456.

8 Drawer S, Fuller CW. Propensity for osteoarthritis and lower limb joint pain in retired professional soccer players. Br J Sports Med 2001;35:402-8.

9 Drawer S, Fuller CW. Evaluating the level of injury in English professional football using a risk based assessment process. Br J Sports Med 2002;36:446-51.

10 Lohmander LS, Ostenberg A, Englund M, et al. High prevalence of knee osteoarthritis, pain, and functional limitations in female soccer players twelve years after anterior cruciate ligament injury. Arthritis Rheum 2004;50:3145-52.

11 von Porat A, Roos EM, Roos H. High prevalence of osteoarthritis 14 years after an anterior cruciate ligament tear in male soccer players: a study of radiographic and patient relevant outcomes. Ann Rheum Dis 2004;63:269-73.

12 van Mechelen W, Hlobil H, Kemper HC, Incidence, severity, aetiology and prevention of sports injuries. A review of concepts. Sports Med 1992;14:82-99.

13 Finch C. A new framework for research leading to sports injury prevention. J Sci Med Sport 2006;9(1-2):3-9.

14 Bahr R, Reeser JC; . Injuries among world-class professional beach volleyball players. The Fédération Internationale de Volleyball beach volleyball injury study. Am J Sports Med 2003;31:119-25.

15 Junge A, Dvorak J, Graf-Baumann T, et al. Football injuries during FIFA tournaments and the Olympic Games, 1998-2001: development and implementation of an injuryreporting system. Am J Sports Med 2004:32:80S-9.

16 Junge A, Dvorak J, Graf-Baumann T. Football injuries during the World Cup 2002. Am J Sports Med 2004:32:23S-7.

17 Dvorak J, Junge A, Grimm K, et al. Medical report from the 2006 FIFA World Cup Germany. Br J Sports Med 2007;41:578-81.

18 Junge A, Dvorak J. Injuries in female football players in top-level international tournaments. Br J Sports Med 2007;41 Suppl 1(Suppl 1):i3-i7.

19 Dvorak J, Junge A, Derman W, et al. Injuries and illnesses of football players during the 2010 FIFA World Cup. Br J Sports Med 2011;45:626-30

20 Junge A, Dvořák J. Football injuries during the 2014 FIFA World Cup. Br J Sports Med 2015;49:599-602.

21 Best JP, McIntosh AS, Savage TN, . Rugby World Cup 2003 injury surveillance project. Br J Sports Med 2003;:39:812-7.

22 Fuller CW, Laborde F, Leather RJ, et al. International Rugby Board Rugby World Cup 2007 injury surveillance study. Br J Sports Med 2008;42:452-9.

23 Fuller CW, Taylor A, Molloy MG. Epidemiological study of injuries in International Rugby Sevens. Clin J Sport Med 2010;20:179-84

24 Taylor AE, Fuller CW, Molloy MG. Injury surveillance during the 2010 IRB Women's Rugby World Cup. Br J Sports Med 2011:45:1243-5.

25 Fuller CW, Sheerin K, Targett S, et al. International Rugby Board injury surveillance study. Br J Sports Med 20112013;47:1184-91;47:1184-91.

26 Fuller CW, Taylor A, Raftery M. 2016 Rio Olympics: an epidemiological study of the men's and women's Rugby-7s tournaments. Br J Sports Med 2017.

27 Hägglund M, Waldén M, Bahr R, et al. Methods for epidemiological study of injuries to professional football players: developing the UEFA model. Br J Sports Med 2005;39:340-6.

28 Waldén $M$, Hägglund M, Ekstrand J. UEFA Champions League study: a prospective study of injuries in professional football during the 2001-2002 season. Br J Sports Med 2005;39:542-6

29 Waldén $M$, Hägglund $M$, Ekstrand J. Football injuries during european championships 2004-2005. Knee Surg Sports Traumatol Arthrosc 2007;15:1155-62.

30 Ekstrand J, Hägglund M, Waldén M. Injury incidence and injury patterns in professional football: the UEFA injury study. Br J Sports Med 2011;45.

31 Hägglund $M$, Waldén $M$, Ekstrand J. UEFA injury study--an injury audit of european championships 2006 to 2008. Br J Sports Med 2009;43:483-9.

32 Hägglund $M$, Waldén $M$, Magnusson $H$, et al. Injuries affect team performance negatively in professional football: an 11-year follow-up of the UEFA Champions League injury study. Br J Sports Med 2013:47:738-42.

33 Webborn N, Willick S, Reeser JC. Injuries among disabled Athletes during the 2002 Winter Paralympic Games. Med Sci Sports Exerc 2006;38:811-5.

34 Webborn N, Willick S, Emery CA. The injury experience at the 2010 winter paralympic games. Clin J Sport Med 2012;22:1-9.

35 Derman W, Schwellnus M, Jordaan E, et al. Illness and injury in Athletes during the competition period at the London 2012 Paralympic Games: development and implementation of a web-based surveillance system (WEB-IISS) for team medical staff. Br J Sports Med 2013;47:420-5.

36 Willick SE, Webborn N, Emery C, et al. The epidemiology of injuries at the London 2012 Paralympic Games. Br J Sports Med 2013:47:426-32.

37 Schwellnus M, Derman W, Jordaan E, et al. Factors associated with illness in Athletes participating in the London 2012 Paralympic Games: a prospective cohort study involving 49,910 athlete-days. Br J Sports Med 2013;47:433-40 
38 Derman W, Schwellnus MP, Jordaan E, et al. High incidence of injury at the Sochi 2014 Winter Paralympic Games: a prospective cohort study of 6564 athlete days. Br J Sports Med 2016;50:1069-74.

39 Derman W, Schwellnus MP, Jordaan E, et al. The incidence and patterns of illness at the Sochi 2014 Winter Paralympic Games: a prospective cohort study of 6564 athlete days. Br J Sports Med 2016;50:1064-8.

40 Alonso JM, Junge A, Renström P, et al. Sports injuries surveillance during the 2007 IAAF World Athletics Championships. Clin J Sport Med 2009;19:26-32.

41 Alonso JM, Tscholl PM, Engebretsen L, et al. Occurrence of injuries and illnesses during the 2009 IAAF World Athletics Championships. Br J Sports Med 2010;44:1100-5.

42 Alonso JM, Edouard $\mathrm{P}$, Fischetto $\mathrm{G}$, et al. Determination of future prevention strategies in elite track and field: analysis of Daegu 2011 IAAF championships injuries and illnesses surveillance. Br J Sports Med 2012;46:505-14.

43 Alonso JM, Jacobsson J, Timpka T, et al. Preparticipation injury complaint is a risk factor for injury: a prospective study of the Moscow 2013 IAAF championships. $\mathrm{Br}$ J Sports Med 2015;49:1118-24.

44 Feddermann-Demont $\mathrm{N}$, Junge A, Edouard $\mathrm{P}$, et al. Injuries in 13 International Athletics championships between 2007-2012. Br J Sports Med 2014;48:513-22.

45 Timpka T, Jacobsson J, Bargoria V, et al. Preparticipation predictors for championship injury and illness: cohort study at the Beijing 2015 International Association of Athletics Federations World Championships. Br J Sports Med 2017:51:271-6.

46 Mountjoy M, Junge A, Alonso JM, et al. Sports injuries and illnesses in the 2009 FINA World Championships (Aquatics). Br J Sports Med 2010;44:522-7.

47 Mountjoy M, Junge A, Benjamen S, et al. Competing with injuries: injuries prior to and during the 15th FINA World Championships 2013 (aquatics). Br J Sports Med 2015;49:37-43

48 Prien A, Mountioy M, Miller J, et al. Injury and illness in aquatic sport: how high is the risk? A comparison of results from three FINA World Championships. Br J Sports Med 2017:51:277-82

49 Flørenes TW, Bere T, Nordsletten L, et al. Injuries among male and female world Cup alpine skiers. Br J Sports Med 2009;43:973-8.

50 Flørenes TW, Heir S, Nordsletten L, et al. Injuries among World Cup freestyle skiers. $\mathrm{Br}$ J Sports Med 2010;44:803-8.

51 Flørenes TW, Nordsletten L, Heir S, et al. Recording injuries among World Cup skiers and snowboarders: a methodological study. Scand J Med Sci Sports 2011:21:196-205.

52 Flørenes TW, Nordsletten L, Heir S, et al. Injuries among World Cup ski and snowboard Athletes. Scand J Med Sci Sports 2012;22:58-66.

53 Bakken A, Bere T, Bahr R, et al. Mechanisms of injuries in World Cup Snowboard Cross: a systematic video analysis of 19 cases. Br J Sports Med 2011:45:1315-22.

54 Bere T, Flørenes TW, Nordsletten L, et al. Sex differences in the risk of injury in World Cup alpine skiers: a 6-year cohort study. Br J Sports Med 2014;48:36-40.

55 Major DH, Steenstrup SE, Bere T, et al. Injury rate and injury pattern among elite world Cup snowboarders: a 6-year cohort study. Br J Sports Med 2014;48:18-22.

56 Randjelovic S, Heir S, Nordsletten L, et al. Injury situations in Freestyle Ski Cross (SX): a video analysis of 33 cases. Br J Sports Med 2014;48:29-35.

57 Steenstrup SE, Bere T, Bahr R. Head injuries among FIS World Cup alpine and freestyle skiers and snowboarders: a 7-year cohort study. Br J Sports Med 2014;48:41-5.

58 Tuominen M, Stuart MJ, Aubry M, et al. Injuries in men's international ice hockey: a 7-year study of the International Ice Hockey Federation Adult World Championship Tournaments and Olympic Winter Games. Br J Sports Med 2015;49:30-6.

59 Tuominen M, Stuart MJ, Aubry M, et al. Injuries in women's international ice hockey: an 8-year study of the World Championship tournaments and Olympic Winter Games. Br J Sports Med 2016;50:1406-12.

60 Tuominen M, Hänninen T, Parkkari J, et al. Concussion in the international ice hockey world championships and olympic Winter Games between 2006 and 2015. Br J Sports Med 2017:51:244-52.

61 Tuominen M, Stuart MJ, Aubry M, et al. Injuries in world junior ice hockey championships between 2006 and 2015. Br J Sports Med 2017:51:36-43.

62 Park KJ, Brian Byung S. Injuries in elite korean fencers: an epidemiological study. Br J Sports Med 2017:51:220-5.

63 Lystad RP, Graham PL, Poulos RG. Exposure-adjusted incidence rates and severity of competition injuries in australian amateur taekwondo Athletes: a 2-year prospective study. Br J Sports Med 2013;47:441-6.

64 Bere T, Alonso JM, Wangensteen A, et al. Injury and illness surveillance during the 24th men's Handball World Championship 2015 in Qatar. Br J Sports Med 2015;49:1151-6.
65 Loosemore M, Lightfoot J, Palmer-Green D, et al. Boxing injury epidemiology in the Great Britain team: a 5-year surveillance study of medically diagnosed injury incidence and outcome. Br J Sports Med 2015;49:1100-7.

66 Siewe J, Rudat J, Zarghooni K, et al. Injuries in competitive boxing. A prospective study. Int J Sports Med 2015;36:249-53.

67 Westermann RW, Giblin M, Vaske A, et al. Evaluation of men's and Women's Gymnastics Injuries: A 10-Year Observational Study. Sports Health 2015;7:161-5

68 Theilen TM, Mueller-Eising W, Wefers Bettink P, et al. Injury data of Major internationa field hockey tournaments. Br J Sports Med 2016;50:657-60.

69 Kim KS, Park KJ, Lee J, et al. Injuries in national olympic level judo Athletes: an epidemiological study. Br J Sports Med 2015;49:1144-50.

70 Brøgger-Jensen T, Hvass I, Bugge S. Injuries at the BMX Cycling European Championship, 1989. Br J Sports Med 1990;24:269-70.

71 Jayanthi NA, O'Boyle J, Durazo-Arvizu RA. Risk factors for medical withdrawals in United States tennis association junior national tennis tournaments: a descriptive epidemiologic study. Sports Health 2009;1:231-5.

72 Lynall RC, Kerr ZY, Djoko A, et al. Epidemiology of National Collegiate Athletic Association men's and women's tennis injuries, 2009/2010-2014/2015. Br J Sports Med 2016:50:1211-6.

73 Maquirriain J, Baglione R. Epidemiology of tennis injuries: an eight-year review of Davis Cup retirements. Eur J Sport Sci 2016;16:266-70.

74 McCurdie I, Smith S, Bell PH, et al. Tennis injury data from the championships, Wimbledon, from 2003 to 2012. Br J Sports Med 2017;51

75 Pluim BM, Loeffen FG, Clarsen B, et al. A one-season prospective study of injuries and illness in elite junior tennis. Scand J Med Sci Sports 2016;26:564-71.

76 Pluim BM, Clarsen B, Verhagen E. Injury rates in recreational tennis players do not differ between different playing surfaces. Br J Sports Med 2017:bjsp orts-2016-097050.

77 Junge A, Engebretsen L, Alonso JM, et al. Injury surveillance in multi-sport events: the International Olympic Committee approach. Br J Sports Med 2008:42:413-21.

78 Junge A, Engebretsen L, Mountjoy ML, et al. Sports injuries during the Summer Olympic Games 2008. Am J Sports Med 2009;37:2165-72.

79 Engebretsen L, Steffen K, Alonso JM, et al. Sports injuries and illnesses during the Winter Olympic Games 2010. Br J Sports Med 2010;44:772-80.

80 Engebretsen L, Soligard T, Steffen K, et al. Sports injuries and illnesses during the London Summer Olympic Games 2012. Br J Sports Med 2013;47:407-14

81 Soligard T, Steffen K, Palmer-Green D, et al. Sports injuries and illnesses in the Sochi 2014 Olympic Winter Games. Br J Sports Med 2015;49:441-7.

82 Bahr R. No injuries, but plenty of pain? on the methodology for recording overuse symptoms in sports. Br J Sports Med 2009;43:966-72

83 Clarsen B, Myklebust G, Bahr R. Development and validation of a new method fo the registration of overuse injuries in sports injury epidemiology: the Oslo Sports Trauma Research Centre (OSTRC) overuse injury questionnaire. Br J Sports Med 2013:47:495-502

84 Clarsen B, Rønsen O, Myklebust G, et al. The Oslo Sports Trauma Research Center questionnaire on health problems: a new approach to prospective monitoring of illness and injury in elite Athletes. Br J Sports Med 2014;48:754-60.

85 Clarsen B, Bahr R. Matching the choice of injury/illness definition to study setting. purpose and design: one size does not fit all! Br J Sports Med 2014;48:510-2.

86 Mountjoy $\mathrm{M}$, Junge $\mathrm{A}$, Alonso JM, et al. Consensus statement on the methodology of injury and illness surveillance in FINA (aquatic sports). Br J Sports Med 2016;50:590-6.

87 Attaran A. Off the Podium: why Public Health concerns for global spread of Zika virus means that Rio de Janeiro's 2016 Olympic Games Must Not Proceed. Harvard Public Health Review 2016 http://harvardpublichealthreview.org/off-the-podium-why-rios2016-olympic-games-must-not-proceed/.

88 World Health Organization. Zika situation report. 2016. http://www.who.int/ emergencies/zika-virus/situation-report/25-august-2016/en/.

89 Sell $\mathrm{K}$, Hainline $\mathrm{B}$, Yorio $\mathrm{M}$, et al. IIlness data from the US open tennis championships from 1994 to 2009. Clin J Sport Med 2013;23:25-32.

90 Fuller CW, Ekstrand J, Junge A, et al. Consensus statement on injury definitions and data collection procedures in studies of football (soccer) injuries. Br J Sports Med 2006;40:193-201.

91 Bahr R, Holme I. Risk factors for sports injuries--a methodological approach. Br J Sports Med 2003;37:384-92.

92 Inklaar H, injuries S. I: incidence and severity. Sports Med 1994;18:55-73.

93 Finch CF. An overview of some definitional issues for sports injury surveillance. Sports Med 1997:24:157-63.

94 The Olympic Movement Medical Code. International Olympic Committee 2016 http:// www.olympic.org/PageFiles/61597/Olympic Movement_Medical_Code eng.pdf. 